\title{
NUTRIENT SIGNATURE OF QUEBEC (CANADA) CRANBERRY (Vaccinium macrocarpon AIT.) ${ }^{1}$
}

\author{
SÉBASTIEN MARCHAND ${ }^{2}$, SERGE-ÉTIENNE PARENT², \\ JEAN-PIERRE DELAND ${ }^{3}$, LÉON-ÉTIENNE PARENT ${ }^{2}$
}

ABSTRACT - Fertilizer recommendations for cranberry crops are guided by plant and soil tests. However, critical tissue concentration ranges used for diagnostic purposes are inherently biased by nutrient interactions and physiological age. Compositional data analysis using isometric log ratios $(i l r)$ of nutrients as well as time detrending can avoid numerical biases. The objective was to derive unbiased nutrient signature standards for cranberry in Quebec and compare those standards to literature data. Field trials were conducted during 3 consecutive years with varying $\mathrm{P}$ treatments at six commercial sites in Quebec. Leaf tissues were analyzed for N, P, K, Ca, Mg, B, Cu, Zn, Mn and Fe. The analytical results were transformed into ilr nutrient balances of parts and groups of parts. High-yield reference ilr values were computed for cranberry yielding greater than $35 \mathrm{Mg} \mathrm{ha}^{-1}$. Many cranberry fields appeared to be over-supplied with $\mathrm{K}$ and either under-supplied with $\mathrm{Mn}$ or over-supplied with $\mathrm{Fe}$ as shown by their imbalanced $[\mathrm{K} \mid \mathrm{Ca}, \mathrm{Mg}]$ and $[\mathrm{Mn} \mid \mathrm{Fe}]$ ratios. Nutrient concentration ranges from Maine and Wisconsin, USA, were combined into ilr values to generate ranges of balances. It was found that these nutrient ranges were much too broad for application in Quebec or outside the Quebec ranges for the $[\mathrm{Ca} \mid \mathrm{Mg}]$ and the $[\mathrm{Mn} \mid \mathrm{Fe}]$ balances, that were lower compared to those of high yielding cranberry crops in Quebec.

Index terms: Compositional Nutrient Diagnosis (CND), isometric log ratio (ilr), Aitchison distance, nutrient balance ranges.

\section{PERFIL NUTRITIVO DE ATOCAS (Vaccinium macrocarpon AIT. - CRANBERRY) CULTIVADAS NO QUÉBEC, CANADÁ}

RESUMO- As recommendações de fertilizantes da cultura atoca são determinadas a partir de análises de planta e solo. No entanto, as faixas críticas de concentração nos tecidos utilizados para fins de diagnóstico são influenciadas por interações de nutrientes e pela idade fisiológica. A análise de dados composicionais log isométricas (ilr) de nutrientes, bem como a idade fisiológica podem ser removidas numéricamente na interpretação dos dados analíticos dos tecidos. Nosso objetivo foi obter padrões imparciais para o perfil nutrivo da atóca, cultivada no Québec, Canadá, e comparar esses padrões com os dados da literatura. Os testes de campo foram realizadas durante 3 anos consecutivos com diferentes tratamentos com fósforo, em seis áreas comerciais do Québec. Os tecidos foliares foram analisados para N, P, K, Ca, Mg, B, Cu, Zn, Mn e Fe. Os resultados analíticos foram transformados em nove ilr. Os valores de referência ilr foram computados a partir de rendimentos de atóca $\geq 35 \mathrm{Mg}$ ha-1. Muitas áreas de atóca parecem ser mais adubadas com $\mathrm{K}$, $\mathrm{Mg}$ ou Fe ou sub-adubadas com Mn, como mostrado pelo desequilíbrio [K $\mid \mathrm{Ca}, \mathrm{Mg}]$ e $[\mathrm{Mn} \mid \mathrm{Fe}]$. Faixas de concentração de nutrientes do Maine e Wisconsin foram combinadas em valores ilr para obter faixas de equilíbrio. As faixas de nutrientes foram mais amplas no Quebec que em outras regiões para os balanços $[\mathrm{Ca} \mid \mathrm{Mg}]$ e $[\mathrm{Mn} \mid \mathrm{Fe}]$, comparando-se a cultira de atoca de alta produtividade no Québec.

Termos de indexação: Diagnose da Composição Nutricional (CND), relação log isométrica (CND-ilr), distância de Aitchison, faixas de balanço nutricional.

'(Trabalho 187-12). Recebido em:18-06-2012. Aceito para publicação em: 30-11-2012.

${ }^{2}$ ERSAM, Department of Soils and Agrifood Engineering, Université Laval, Québec (Qc), Canada G1V 0A6. Email: sebastien. marchand.4@ulaval.ca

${ }^{3}$ CETAQ, 859 Ancienne rue de l'Église, Notre-Dame-de-Lourdes (Qc), Canada G0S 1T0. Email : jpdeland@cetaq.qc.ca Corresponding author: Léon-Étienne Parent, ERSAM, Department of Soils and Agrifood Engineering, Université Laval, Québec (Qc), Canada G1V 0A6. E-mail: leon-etienne.parent@fsaa.ulaval.ca 


\section{INTRODUCTION}

Cranberry (Vaccinium macrocarpon Ait.) ('Atoca' or 'Ataca' in the Iroquoian languages, a designation commonly used in the province of Quebec, Canada) is the American name for an Ericaceous plant domesticated in North America since the beginning of the $19^{\text {th }}$ century, and since 1939 in Quebec, Canada. Cranberry is selected since 1835 for commercially viable traits such as fruit yield and quality (ROPER; VORSA, 1997). Ripening berries change from white and firm to red, fleshy and juicy. The berry has a high anti-oxidant content and is consumed as dried fruit, sauce or juice. The current area of cultivated cranberry in Quebec is 3,250 ha. Plantations are established in low-lying landscape positions to facilitate water management (PARENT \& MARCHAND, 2006).

For establishment, cranberry vines are spread onto acid peat or podzolic sands and disc-harrowed slightly into the ground. Cranberry is harvested by flooding 1-2 ha beds and floating the berries. The most important yield determinants of cranberry are floral induction and fruit set as influenced by $\mathrm{C}$ allocation, weather conditions and genetics (ROPER, 2006). Sanding and pruning reduce the effect of alternate bearing (i.e. biennal cycle of high and low yields) on berry productivity (ROPER, 2006).

Cranberry fertilization is guided by tissue and soil tests (YARBOROUGH et al., 1993). The goal of tissue testing is to insure that nutrients do not limit photosynthesis and yield. Plant nutrient status is generally assessed from elemental composition of selected cranberry tissues (leaves from bearing and non-bearing uprights). However, the diagnosis of individual nutrients is known to be biased by nutrient interactions and physiological age (BATES, 1971). Alternatively, nutrient ratios (WALWORTH; SUMNER, 1987) or log ratios (PARENT; DAFIR, 1992; PARENT, 2011) facilitate the interpretation of nutrient interactions and may also account for nutrient dilution and accumulation in plant tissues and the effect of physiological age on nutrient concentration in cranberry leaves as shown by Marks and Taylor (1972).

Compositional data analysis provides techniques to address the special numerical properties of compositional data. Tissue analytical data are compositional, i.e. strictly positive data closed by some unit of measurement. Because the $D^{\text {th }}$ component of a $D$-part composition can be computed by difference between the unit of measurement and the sum of others, one component is redundant. Hence there are $D-1$ degrees of freedom in compositional vectors closed to $100 \%$ (EGOZCUE; PAWLOWSKY-GLAHN, 2005). By comparison, there is $D \times(D-1)$ dual ratios in a $D$-parts composition. Most dual-ratios are thus redundant. The Diagnosis and Recommendation Integrated System (DRIS) (Walworth and Sumner, 1987), and its correct formulation in terms of row-centred log ratios (PARENT; DAFIR, 1992) in Compositional Nutrient Diagnosis, diagnoses $D$ nutrient indexes adding up to zero, therefore, one of them is redundant. Although intrinsically at fault, most multivariate analyses of nutrient signatures or 'ionomes' are conducted using $D$ raw nutrient concentrations (LAHNER et al., 2003; CONN; GILLIHAM, 2010) or their basic log transformation (HAN et al., 2011), hence ignoring nutrient interactions and information redundancy.

An unbiased diagnosis that avoids redundancy requires reducing a $D$-part compositional vector to $D-1$ meaningful balances of nutrients as orthogonal $\log$ contrasts. The ilr approach is the most convenient to describe natural patterns and balances in plant nutrition (PARENT, 2011).

Our objectives were (1) to derive nutrient balance standards for productive cranberry using ilr coordinates as unbiased nutrient indexes, (2) to compare Quebec ilr standards to literature data and (3) to test the effect of physiological age on nutrient balances.

Compositional model

The compositional space is defined by $S^{D}$ and the closure operation $(C)$ as follows:

$S^{D}=C\left(c_{1}, c_{2}, \ldots c_{D}\right)=\left[\frac{c_{1} x}{\sum_{i=1}^{D} c_{i}}, \frac{c_{2} x}{\sum_{i=1}^{D} c_{i}}, \ldots \frac{c_{D} x}{\sum_{i=1}^{D} c_{i}},\right]$

Where $\kappa$ is the unit of measurement, such as $1,100 \%, 1000 \mathrm{~g} \mathrm{~kg}^{-1}$, etc., and $c_{i}$ is the ith part of a composition containing $D$ parts. A filling value $\left(F_{v}\right)$ is computed by difference between the unit of measurement and the sum of analytical results.

The $i l r$ technique allows projecting $S^{D}$ into the Euclidean space of $D-1$ orthonormal axes. Doing so, we compute the "coordinates" of $S^{D}$. Each coordinate is a log ratio of parts or groups of parts that can be defined in a sequential binary partition (SBP). A SBP is a (D-1) $\times D$ matrix, in which parts labeled " +1 " (group numerator) are balanced with parts labeled "-1" (group denominator) in each ordered row (see Table 1 for an example). A part labeled " 0 " is excluded from the balance (binary partition) between parts. The composition is partitioned sequentially at every ordered row into 2 contrasts until the $(+1)$ and (-1) subcompositions each contain a single part. 
Each ilr coordinate is computed as follows (EGOZCUE; PAWLOWSKY-GLAHN, 2005):

$i l r_{j}=\sqrt{\frac{r s}{r+s}} \ln \frac{g\left(c_{+}\right)}{g\left(c_{-}\right)}$with $\mathrm{j}=[1,2, \ldots, D-1]$

Where $i l r_{j}$ is the $j^{\text {th }}$ isometric $\log$ ratio, $r$ and $s$ are, respectively, numbers of components in the numerator) and denominator, respectively (as defined in the SBP), $g\left(c_{+}\right)$is geometric mean of components in the numerator and $g(c)$ is geometric mean of components in denominator.

Applied to plant nutrition data, this technique provides a geometric framework whereby each ilr coordinate represents a dimension of plant nutrient signature or profile projected into the Euclidean space. The Aitchison distance, $\mathrm{A}(\mathrm{x}, \mathrm{y})$, between two $D$-parts compositions in the Euclidean space can be computed across the ilr coordinates, as follows (EGOZCUE; PAWLOWSKY-GLAHN, 2006):

$$
A(x, y)=\sqrt{\sum_{j=1}^{D-1}\left(i l r_{j}-i l r_{j}^{*}\right)^{2}}
$$

Where * indicates the ilr coordinate of the reference composition. Such distance computed across raw or simple log-transformed concentration data is geometrically irrelevant (AITCHINSON, 1986).

\section{MATERIAL AND METHODS}

\section{Experimental setup}

Tissue analytical data and fruit yields were obtained from six P trials on cranberry (cv. 'Stevens') established on sandy soils (PARENT \& MARCHAND, 2006) in Quebec, Canada (46 $13^{\circ} \mathrm{N}$ to $46^{\circ} 18^{\prime} \mathrm{N}$; $71^{\circ} 45^{\prime} \mathrm{W}$ to $\left.71^{\circ} 59^{\prime} \mathrm{W}\right)$. There were 202 observations over 3 years (2001 to 2003). Treatments were applied each year onto $2 \mathrm{~m}$ by $3 \mathrm{~m}$ plots. The $\mathrm{P}$ treatments varied between $0,33,66$ and $99 \mathrm{~kg} \mathrm{P}^{-1}$ in 2000 and $0,13,26$ and $39 \mathrm{~kg} \mathrm{P} \mathrm{ha-1} \mathrm{yr}^{-1}$ applied yearly in 2001 and 2002 on plots different than those used in 2000. The $\mathrm{N}$ was applied at a rate of $40 \mathrm{~kg}$ $\mathrm{NH}_{4}-\mathrm{N} \mathrm{ha}^{-1}$ as ammonium sulfate. Potassium sulfate was added to provide $133 \mathrm{~kg} \mathrm{~K} \mathrm{ha}^{-1}$. Fertilizers were broadcast in four equal monthly applications starting in mid-June-early July. Berry yield was measured on five randomly assigned subareas totaling 0.45 $\mathrm{m}^{2}$ in each plot.

\section{Plant analysis}

In each plot, 100 current season's uprights were collected from fruit-bearing and nonfructiferous upright stems between mid-August and mid-September as prescribed by DEMORANVILLE \& DEUBERT (1986) and DAVENPORT et al. (1995). Tissue samples were oven-dried at $65^{\circ} \mathrm{C}$ for $24 \mathrm{~h}$ to $36 \mathrm{~h}$, ground to $<2 \mathrm{~mm}$, and analyzed for total N, P, K, Ca, Mg, Zn, Cu, Mn, Fe, and B. Total $\mathrm{N}$ was determined by micro-Kjeldahl digestion and distillation (JONES; CASE, 1990). Other elements were quantified by plasma emission spectroscopy after tissue digestion in a perchloric $\left(\mathrm{HClO}_{4}\right)$ and nitric $\left(\mathrm{HNO}_{3}\right)$ acid mixture (JONES;CASE, 1990).

\section{Statistical analysis}

Statistical computations were conducted in the $\mathrm{R}$ statistical environment ( $\mathrm{R}$ DEVELOPMENT CORE TEAM, 2011). The ilr computations were conducted using the $\mathrm{R}$ "compositions" package. Multivariate outliers were removed using the Mahalanobis distance at a 0.01 level of significance using the R "mvoutlier" package.

The Aitchison distance was used as an index of nutrient balance. Aitchison distances are computed between the ilr coordinates of the observations and the reference, corresponding to the means of $i l r$ coordinates of high yield observations. The yield cutoff between the high- and low-productivity groups was set at maximum number of true positive and true negative observations about the critical Aitchison distance using the Cate-Nelson partitioning procedure (NELSON \& ANDERSON, 1984), with at least 20 observations (readjusted to 25 after the Cate-Nelson optimization) in true negative group. Quadrants were classified according to the yield/index crosschecks for nutrient imbalance as follows (http://www. medstats.org/sens-spec): true positive (TP: low yields correctly diagnosed as imbalanced); false positive (FP: type I error) where high yields were incorrectly identified as imbalanced; true negative (TN: high yields correctly diagnosed as balanced); false negative (FN: type II error) where low yields were incorrectly identified as balanced. Index sensitivity computed as $\mathrm{TP} /(\mathrm{TP}+\mathrm{FN})$ is the power of the test. Quebec balance standards were validated against nutrient ranges used in Maine (YARBOROUGH et al., 1993) and Wisconsin (ROPER, 2001), USA. Lower concentration limits were placed at numerator and upper limits at denominator of the balances and vice versa to generate the lower and upper limits of nutrient balances, respectively.

As statistical test for balance stationarity, the mean time functions of balances were represented by 
a deterministic trend of time using standard regression analysis. Trend analysis was conducted using nutrient data retrieved from (CHAPLIN; MARTIN, 1979) and (DEMORANVILLE; DEUBERT 1986).

\section{RESULTS AND DISCUSSION}

\section{Site productivity}

Average yields varied between 8 and 66 $\mathrm{Mg} \mathrm{ha}^{-1}$ in the experimental plots compared to the range between 2 and $44 \mathrm{Mg} \mathrm{ha}^{-1}$ generally obtained by farmers because plot yield measurement may overestimate farmer's yield by $30 \%$ (PARENT; MARCHAND.

Large yield variation is due to $\mathrm{C}$ allocation by the plant and environmental factors that influence physiological processes. Cranberry has a biennal pattern (PARENT; MARCHAND, 2006) because individual uprights tend to flower every other year (ROPER, 2006). Current season growth is a primary source of carbohydrate for fruit growth and development (ROPER; VORSA, 1997). Within the same year, cranberry yield is limited by the degree of pollination that drives floral induction (proportion of fruiting uprights) and fruit set (number of fruits set from flowers present on a flowering upright) as well as competition between uprights for available C (ROPER, 2006).

\section{Sequential binary partition (SBP)}

Ten ilr coordinates were defined from the 11 components (Table 1). We separated macrofrom micro-nutrients (except $\mathrm{B}$ that is associated) with macro-nutrients (MALAVOLTA, 2006). Macronutrient balances were arranged according to Parent (2011). Micronutrients were set apart as $\mathrm{Cu}$ and $\mathrm{Zn}$ versus $\mathrm{Mn}$ and $\mathrm{Fe}$, since $\mathrm{Cu}$ and $\mathrm{Zn}$ are related to disease management (fungicides) and $\mathrm{Mn}$ and $\mathrm{Fe}$ are closely related to soil genesis. The $10^{\text {th }}$ $i l r$, computed as,

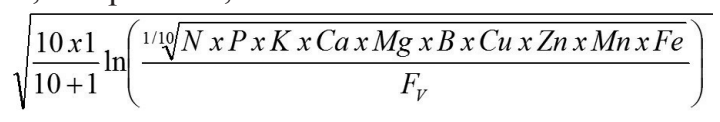

is the remaining contrast between nutrients and the filling value. This choice of SBP can be modified depending on the objective of the study, e.g. one may consider N-P-K or $\mathrm{Cu}-\mathrm{Zn}-\mathrm{Mn}$ subcompositions to interpret fertilizer and fungicide management issues, respectively. However, the Aitchison distance across $i l r$ values remains the same whatever the SBP (the $i l r$ technique projects compositional data in a real space and the SBP defines the Cartesian system). Only the interpretation of individual $i l r$ will be facilitated.

The nutrient balance concept provides an unbiased measure of nutrient imbalance. However, optimal ratios between nutrients were thought to be insufficient criteria for diagnosis because it is impossible at to determine whether a nutrient level is too high or too low in the ratio (WALWORTH; SUMNER, 1987; MARSCHNER, 1995). Nutrient concentration values are thus useful for indicating whether a nutrient is too high and too low, but their diagnoses are biased. Hence, nutrient diagnosis should be conducted using ilr coordinates as assisted by nutrient concentrations to identify the most imbalanced nutrients. As long as at least one or some nutrients become deficient or in excess, nutrient imbalance can be detected as large Aitchison distance from standards. Nutrient imbalance involving simultaneously several deficient nutrients is not likely to occur in intensive production systems at high yield level.

\section{Nutrient signature of Quebec cranberry}

The dataset contained 35 outliers, hence leaving 167 observations. The Cate-Nelson procedure partitioned the dataset into two subpopulations at yield cut-off of $35 \mathrm{Mg} \mathrm{ha}^{-1}$ (Fig. 1). There were 73 true positive (TP) specimens and 25 true negative (TN) observations for a total of observations in the true quadrants. There were 24 false positive (FP) specimens, indicating luxury consumption of nutrients or nutrient contamination. Luxury consumption of nutrients by cranberry plants, especially K, has been reported (ROPER, 2010). On the other hand, fungicide $(\mathrm{Cu}, \mathrm{Zn}$, and $\mathrm{Mn})$ applications vary widely depending on cultivar. The cranberry fields are also established on a wide variety of soils, from organic soils to podzolic sands, hence within broad ranges of $\mathrm{Mn}$ and $\mathrm{Fe}$ availability. There were 45 false negative (FN) specimens, indicating that a factor other than the ones quantified in the compositional vector was limiting berry yield. Test sensitivity was $75 \%$ (73 TP divided by 97 as FP+TP).

The [N.P.K, $\mathrm{Ca}, \mathrm{Mg} \mid \mathrm{B}]$ and $[\mathrm{K} \mid \mathrm{Ca}, \mathrm{Mg}]$ balances were significantly $(\mathrm{P}<0.01)$ lower in the TN than in the TP specimens (Fig. 2) as impacted by higher K concentration in TP (Table 2). Roper (2010) found no gain in berry yield or quality between control and $\mathrm{K}$ fertilization where leaf $\mathrm{K}$ concentration increase significantly from 0.57 to $1.04 \%$, i.e. within confidence interval for the Quebec low yielders and beyond the confidence interval for $\mathrm{K}$ concentrations associated with Quebec TN specimens (Table 2).

The $[\mathrm{Mn} \mid \mathrm{Fe}]$ balance was much higher in the TN compared to TP due to much lower Fe concentration in TN (Table 2). Since the cv. 'Stevens' is not likely to receive fungicides, the Mn 
concentration in cranberry leaves is attributable to $\mathrm{Mn}$ and $\mathrm{Fe}$ availabilities in soils. The relationship between $\mathrm{Mn}$ and $\mathrm{Fe}$ has been little studied. In Nova Scotia, Canada, (LOCKHART; LANGILLE, 1962) measured $\mathrm{Mn} / \mathrm{Fe}$ ratios of $13-55$ in the leaves of lowbush blueberry (Vaccinium angustifolium Ait.), an acidophilic Ericaceous plant like cranberry, indicating possible interference of Mn with the uptake and utilization of iron at low $\mathrm{pH}$ values. In view of the large differences in [Mn $\mid \mathrm{Fe}]$ balance between TP and TN specimens, $\mathrm{Mn}$ and Fe fertilization issues should be addressed in future research in relation with soil genesis.

Although the N/P or Redfield ratio generally varies between 14 and 16 in balanced wild species (AERTS \& CHAPIN, 2000), the $[\mathrm{N} \mid \mathrm{P}]$ balanced varied between 1.588 and 1.671 in the leaf of highly productive cranberry, corresponding to N/P ratios close to 10 . The cranberry plant thus appeared to be either N-deficient or excessively supplied with $\mathrm{P}$. This important aspect should be further addressed in relation to N-P fertilization and environmental concerns with the eutrophication of surface waters by off-farm P losses (PARENT; MARCHAND, 2006).

\section{Comparison of Quebec with Wisconsin and Maine standards}

Compared to the Wisconsin and Maine standards, tissue $\mathrm{N}, \mathrm{Ca}$ or $\mathrm{Mn}$ concentrations were found to be higher in the Quebec TN specimens (Table 2). The balance ranges for Wisconsin nutrient standards (ROPER, 2001) overlapped confidence intervals of Quebec nutrient balances for both TP and $\mathrm{TN}$ specimens (Table 3). The Maine $[\mathrm{Cu}, \mathrm{Zn}$ $\mid \mathrm{Mn}, \mathrm{Fe}]$ and $[\mathrm{Mn} \mid \mathrm{Fe}]$ balance was higher due to higher Mn concentrations in Quebec TN specimens (Table 2). Hence, the balance ranges for computed Wisconsin and Maine balance standards appeared to be too broad to diagnose nutrient imbalance in Quebec cranberry.

Confidence intervals of nutrient balances (Table 3) should be interpreted with care, because the intersecting orthogonal parallel lines delineating the ilr ranges form rectangles while their statistical distributions as confidence regions are elliptical (Fig. 3 for macronutrient balances and Fig. 4 for micronutrient balances). Ellipses for Quebec TN and TP specimens were drawn at the $\mathrm{P}=0.01$ level of significance. The critical balances computed from the Wisconsin and Maine standards (dashed rectangles) were not sensitive enough for classifying correctly the Quebec TN and TP specimens.

The nutrient balance standards could not be further validated by US fertilizer trials. Information on the relationship between cranberry yield and quality and leaf nutrient concentrations is scanty. (DAVENPORT; PROVOST, 1994) presented results of $\mathrm{N}$ fertilizer trials but berry yields were rather low (13.2-18.4 $\mathrm{Mg} \mathrm{ha}^{-1}$ ) and the cranberry was not responsive to added $\mathrm{N}$ despite the low $\mathrm{N} / \mathrm{P}$ ratios between 6.2 and 9.6. Compared to the nutrient ranges presented in Table 2, leaf $\mathrm{N}$ concentrations were rather low and the concentration of metals, especially $\mathrm{Fe}$ and $\mathrm{Cu}$, were very variable among sites and possibly contaminated or at toxic levels (up to $90 \mathrm{mg} \mathrm{Cu} \mathrm{kg}^{-1}$ and $882 \mathrm{mg} \mathrm{Fe} \mathrm{kg}^{-1}$ ).

\section{Trend analysis}

INGESTAD $(1987,1997)$ claimed that nutrient balance scaled on $\mathrm{N}$ concentration must stay constant over time for optimum growth of plant seedlings. Trend analysis showed that three of ten balances were stationary in two US studies (CHAPLIN \& MARTIN, 1979; DEMORANVILLE \& DEUBERT, 1986) but that the $\mathrm{R}^{2}$ values for linear trends were low $(<0.44)$ (Fig. 5).

The $[\mathrm{Ca} \mid \mathrm{Mg}]$ and $[\mathrm{N} \mid \mathrm{P}]$ balances were expected to be stationary, because $\mathrm{Ca}$ and $\mathrm{Mg}$, on the one hand, and $\mathrm{N}$ and $\mathrm{P}$, on the other, generally change in the same direction with time (WALWORTH \& SUMNER, 1987). The [Ca $\mid \mathrm{Mg}]$ balance was found to be stationary while the $[\mathrm{N} \mid \mathrm{P}]$ balance showed a weak ascending linear trend significant at the 0.05 level. The $[\mathrm{Cu} \mid \mathrm{Zn}]$ balance was stationary. The $[\mathrm{N}$, $\mathrm{P}, \mathrm{K}, \mathrm{Ca}, \mathrm{Mg}, \mathrm{B} \mid \mathrm{Cu}, \mathrm{Zn}, \mathrm{Mn}, \mathrm{Fe}]$ balance showed the most significant linear trend $\left(\mathrm{R}^{2}=0.44, \mathrm{P}<0.001\right)$. The [N, P, K, Ca, Mg, B $\mid \mathrm{Cu}, \mathrm{Zn}, \mathrm{Mn}, \mathrm{Fe}],[\mathrm{N}, \mathrm{P}$, $\mathrm{K}, \mathrm{Ca}, \mathrm{Mg} \mid \mathrm{B}]$ and $[\mathrm{N}, \mathrm{P} \mid \mathrm{K}, \mathrm{Ca}, \mathrm{Mg}]$ and $[\mathrm{K} \mid \mathrm{Ca}$, $\mathrm{Mg}$ ] balances showed significantly decreasing linear trends. Most balances should thus be detrended from the sampling date to the physiological age for which balance standards were developed. 
TABLE 1 - Squential binary partitions of cranberry leaf analytical data to compute.

\begin{tabular}{llllllllllllll}
\hline Ilr & $\mathrm{N}$ & $\mathrm{P}$ & $\mathrm{K}$ & $\mathrm{Ca}$ & $\mathrm{Mg}$ & $\mathrm{B}$ & $\mathrm{Cu}$ & $\mathrm{Zn}$ & $\mathrm{Mn}$ & $\mathrm{Fe}$ & $\mathrm{r}$ & $\mathrm{s}$ & Formula
\end{tabular}

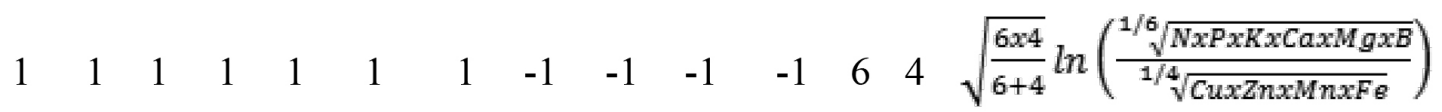

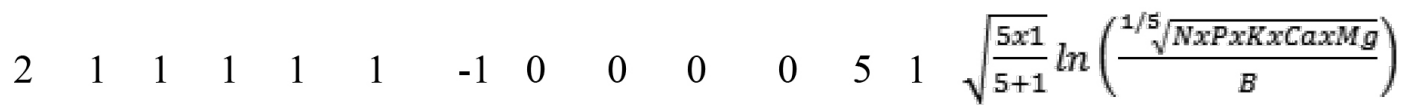

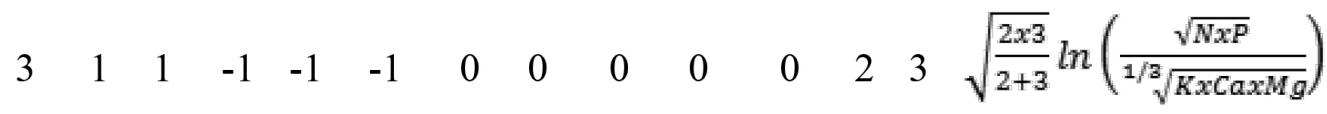

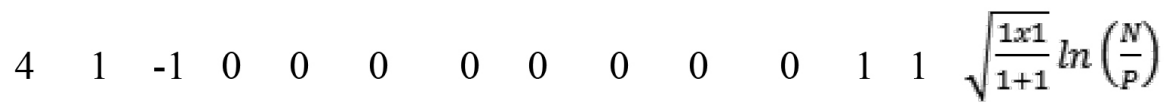

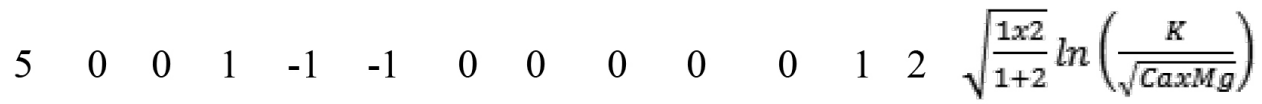

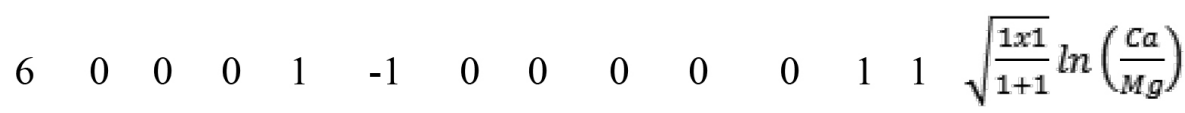

$\begin{array}{llllllllllllll}7 & 0 & 0 & 0 & 0 & 0 & 0 & 1 & 1 & -1 & -1 & 2 & 2 & \sqrt{\frac{2 x 2}{2+2}} \ln \left(\frac{\sqrt{C u x Z n}}{\sqrt{M n x F \varepsilon}}\right)\end{array}$

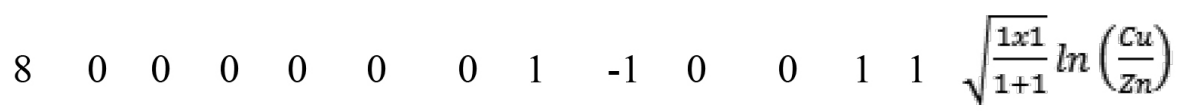

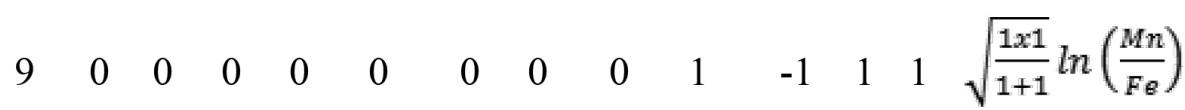


TABLE 2- Concentration intervals $(\mathrm{P}=0.01)$ for low- and high berry-yielding groups in Quebec compared to adequate nutrient ranges for cranberry in Maine (Yarborough et al., 1993) and Wisconsin (Roper, 2001).

\begin{tabular}{|c|c|c|c|c|}
\hline \multirow[t]{2}{*}{ Nutrient } & \multicolumn{2}{|c|}{ Low yielders } & \multicolumn{2}{|c|}{ High yielders } \\
\hline & Minimum & Maximum & Minimum & Maximum \\
\hline & \multicolumn{4}{|c|}{$\%$} \\
\hline $\mathrm{N}$ & 1.15 & 1.24 & 1.09 & 1.24 \\
\hline $\mathrm{P}$ & 0.11 & 0.13 & 0.11 & 0.13 \\
\hline $\mathrm{K}$ & 0.61 & $0.66 \dagger$ & 0.50 & 0.56 \\
\hline $\mathrm{Ca}$ & 0.84 & 1.00 & 0.84 & 1.00 \\
\hline \multirow[t]{2}{*}{$\mathrm{Mg}$} & 0.16 & 0.18 & 0.17 & 0.20 \\
\hline & \multicolumn{4}{|c|}{$\mathrm{mg} \mathrm{kg}^{-1}$} \\
\hline B & 27 & 35 & 30 & 39 \\
\hline $\mathrm{Cu}$ & 4 & 5 & 4 & 5 \\
\hline $\mathrm{Zn}$ & 19 & 23 & 22 & 26 \\
\hline $\mathrm{Mn}$ & 245 & 521 & 493 & 711 \\
\hline \multirow[t]{4}{*}{$\mathrm{Fe}$} & 140 & $183 \dagger$ & 60 & 69 \\
\hline & \multicolumn{2}{|c|}{ Yarborough et al. (1993) } & \multicolumn{2}{|c|}{ Roper (2001) } \\
\hline & Minimum & Maximum & Minimum & Maximum \\
\hline & \multicolumn{4}{|c|}{$\%$} \\
\hline $\mathrm{N}$ & 0.95 & $1.05 \dagger$ & 0.90 & 1.10 \\
\hline $\mathrm{P}$ & 0.11 & 0.14 & 0.10 & 0.20 \\
\hline $\mathrm{K}$ & 0.40 & 0.65 & 0.40 & 0.75 \\
\hline $\mathrm{Ca}$ & 0.60 & $0.80 \dagger$ & 0.30 & $0.80 \dagger$ \\
\hline $\mathrm{Mg}$ & 0.20 & 0.25 & 0.15 & 0.25 \\
\hline & \multicolumn{4}{|c|}{$\mathrm{mg} \mathrm{kg}^{-1}$} \\
\hline $\mathrm{B}$ & 30 & 50 & 15 & 60 \\
\hline $\mathrm{Cu}$ & 4 & 7 & 4 & 10 \\
\hline $\mathrm{Zn}$ & 15 & 30 & 15 & 30 \\
\hline $\mathrm{Mn}$ & 150. & $250 \dagger$ & $>10$ & \\
\hline $\mathrm{Fe}$ & 40 & 80 & $>20$ & \\
\hline
\end{tabular}

$\dagger$ Range outside the confidence interval $(\mathrm{P} \leq 0.01)$ for high yielders.

TABLE 3- Nutrient balance ranges computed from upper and lower limits of Maine (YARBOROUGH et al., 1993) and Wisconsin (ROPER, 2001) concentration ranges compared to balance ranges for high-yield cranberry specimens $\left(>35 \mathrm{Mg} \mathrm{ha}^{-1}\right)$ at Quebec experimental sites (confidence intervals at $\mathrm{P}=0.01$ )

\begin{tabular}{ccccccc}
\hline Balance & \multicolumn{2}{c}{ Yarborough et al.(1993) } & \multicolumn{2}{c}{ Roper (2001) } & \multicolumn{2}{c}{ Quebec high yielders } \\
\hline & Minimum & Maximum & Minimum & Maximum & Minimum & Maximum \\
\hline$[\mathrm{N}, \mathrm{P}, \mathrm{K}, \mathrm{Ca}, \mathrm{Mg}, \mathrm{B}, \mathrm{Cu}, \mathrm{Zn}, \mathrm{Mn}, \mathrm{Fe} \mid \mathrm{Fv}]$ & -7.647 & -7.368 & - & - & -7.400 & -7.320 \\
{$[\mathrm{~N}, \mathrm{P}, \mathrm{K}, \mathrm{Ca}, \mathrm{Mg}, \mathrm{B}] \mid[\mathrm{Cu}, \mathrm{Zn}, \mathrm{Mn}, \mathrm{Fe}]$} & 5.683 & 6.690 & - & - & 5.632 & 5.881 \\
{$[\mathrm{~N}, \mathrm{P}, \mathrm{K}, \mathrm{Ca}, \mathrm{Mg}] \mid \mathrm{B}$} & 3.904 & 4.541 & 3.604 & 5.253 & 4.328 & 4.480 \\
{$[\mathrm{~N}, \mathrm{P}] \mid[\mathrm{K}, \mathrm{Ca}, \mathrm{Mg}]$} & -0.442 & 0.012 & -0.565 & 0.550 & -0.247 & -0.157 \\
{$[\mathrm{~N} \mid \mathrm{P}]$} & 1.355 & 1.594 & 1.068 & 1.694 & 1.568 & 1.648 \\
{$[\mathrm{~K} \mid \mathrm{Ca}, \mathrm{Mg}]$} & -0.079 & 0.503 & -0.071 & 0.994 & 0.862 & 0.969 \\
{$[\mathrm{Ca} \mid \mathrm{Mg}]$} & 0.620 & 0.978 & 0.132 & 1.182 & 0.745 & 0.840 \\
{$[\mathrm{Cu}, \mathrm{Zn} \mid \mathrm{Mn}, \mathrm{Fe}]$} & -2.822 & $-1.758 \dagger$ & - & - & -3.104 & -2.908 \\
{$[\mathrm{Cu} \mid \mathrm{Zn}]$} & -1.420 & -0.547 & -1.417 & -0.296 & 0.274 & 0.309 \\
{$[\mathrm{Mn} \mid \mathrm{Fe}]$} & 0.452 & 1.289 & - & - & 0.947 & 1.534 \\
\hline
\end{tabular}

$\dagger$ Range outside the confidence interval $(\mathrm{P} \leq 0.01)$ for high yielders. 


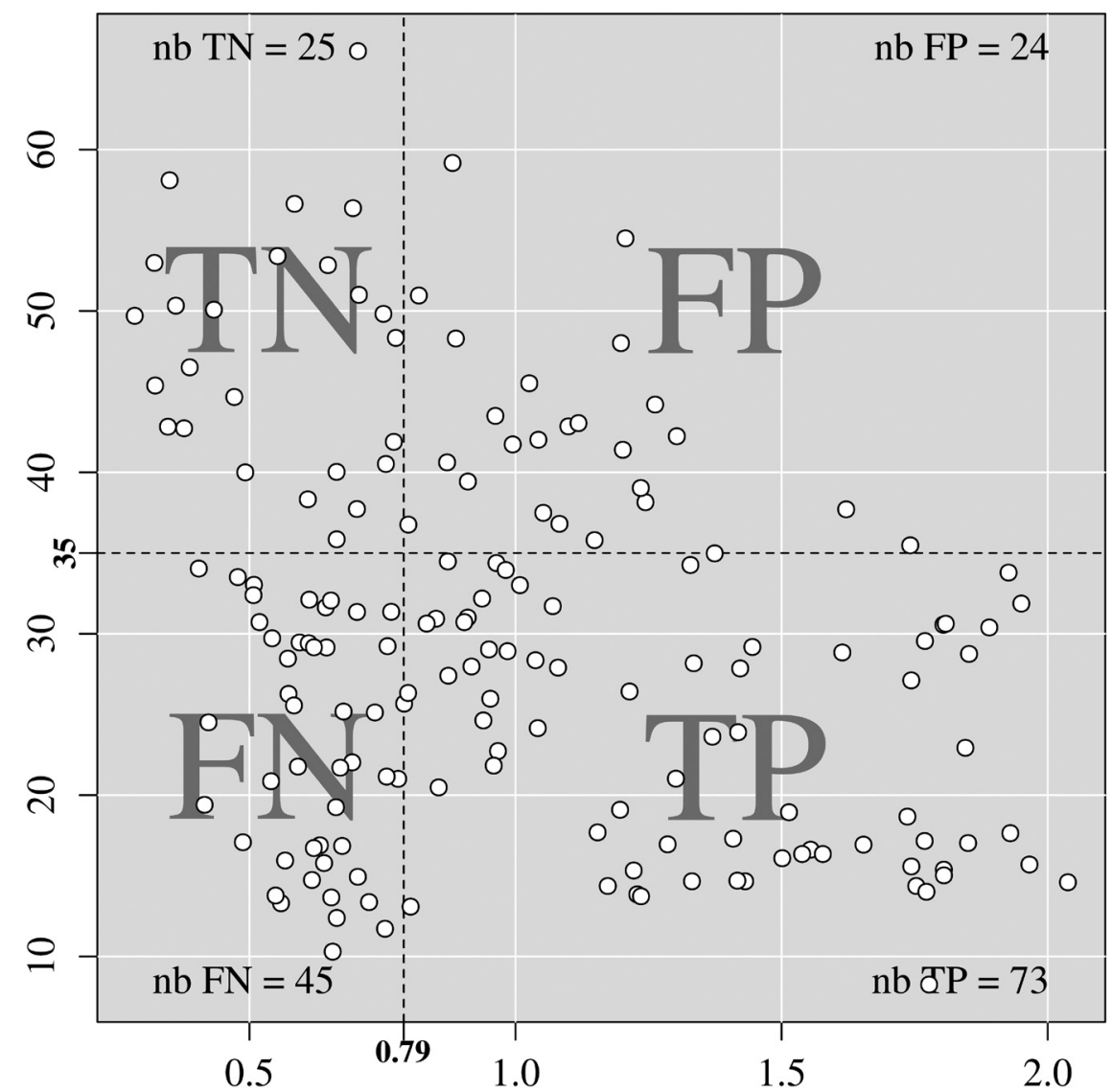

FIGURA 1- Cate-Nelson partitioning of the Aitchison distance from the 25 topmost yielding cranberry stands across 9 nutrient balances expressed as ilr coordinates. The critical Aitchison distance is 0.79 and cutoff yield is $35 \mathrm{Mg}$ berry $\mathrm{ha}^{-1}$.

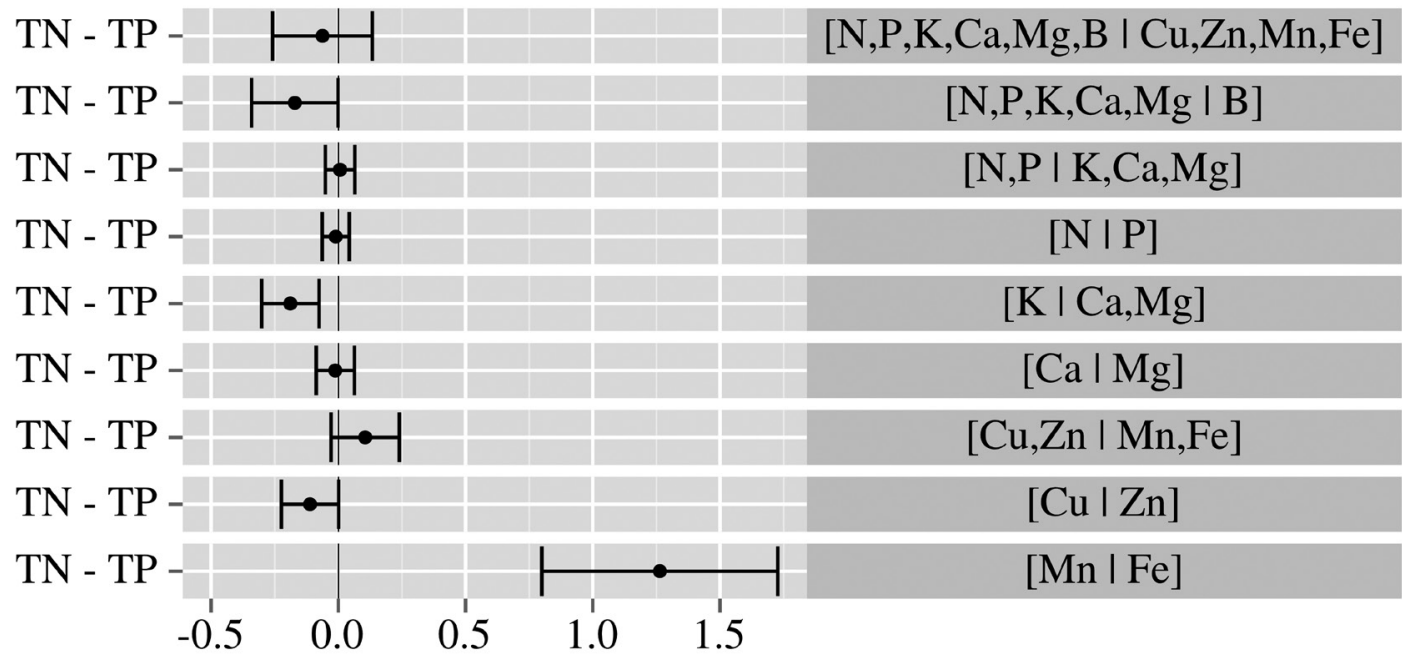

FIGURA 2 - Tukey's test of significance $(\mathrm{P} \leq 0.05)$ between true negative $(\mathrm{TN})$ and true positive $(\mathrm{TP})$ cranberry stands in Quebec experiments. 

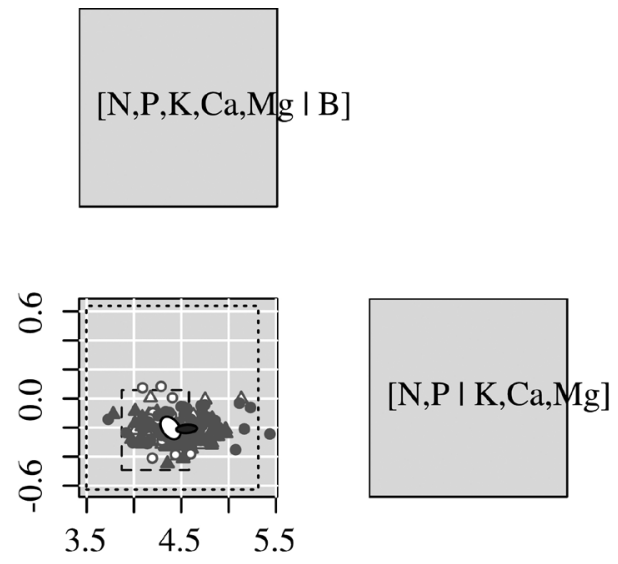

- True positive

- True negative

- False positive

$\triangle$ False negative

- Confidence ellipse: true positive

Confidence ellipse: true negative

Wisconsin standards

I- Maine standards
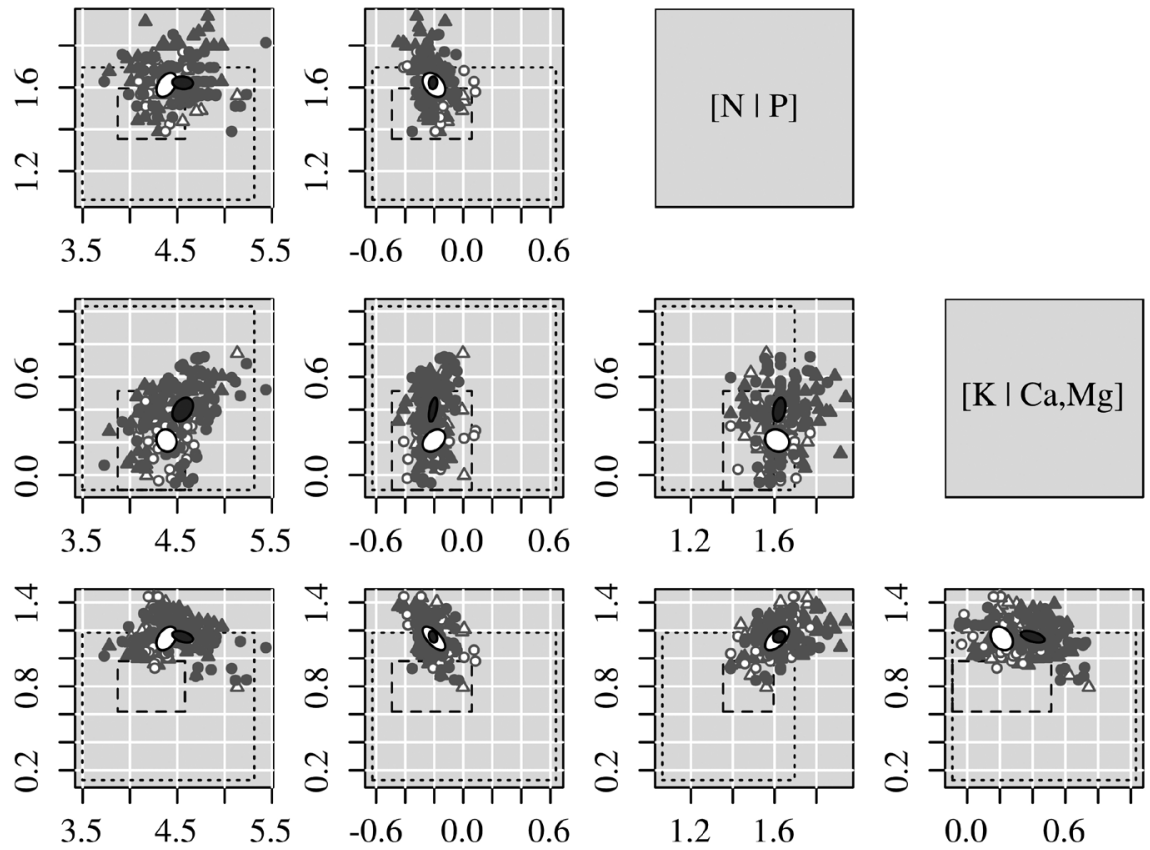

$[\mathrm{Ca} \mid \mathrm{Mg}]$

FIGURA 3 - Elliptical confidence regions at a 0.01 level about mean of macronutrient $i l r$ coordinates for Quebec true positive and true negative specimens. Balance ranges for Maine and Wisconsin (USA) nutrient concentration ranges are presented as dashed squares. 

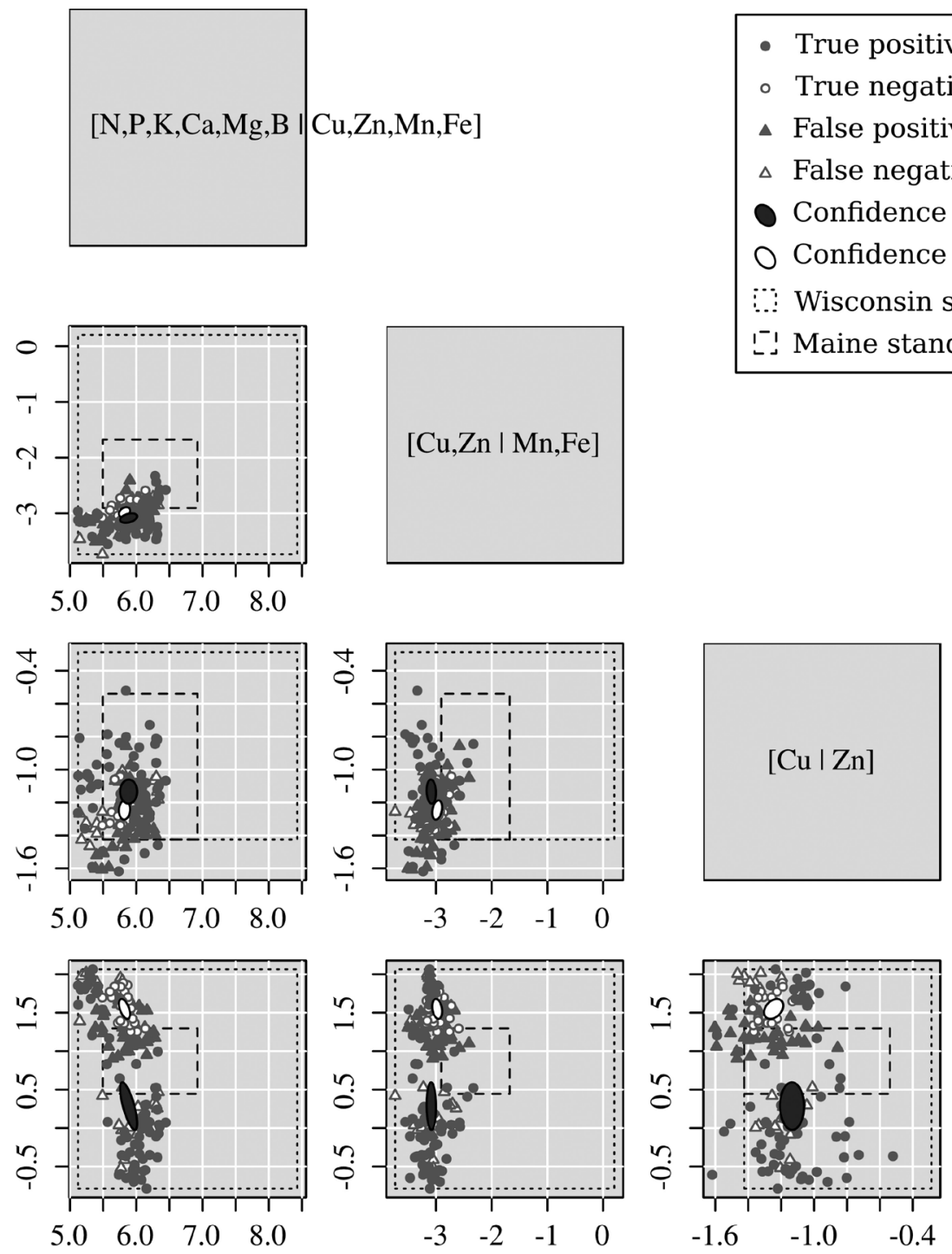

FIGURA 4-Elliptical confidence regions at a 0.01 level about mean of micronutrient ilr coordinates for Quebec true positive and true negative specimens. Balance ranges for Maine (USA) nutrient concentration ranges are presented as dashed squares. 

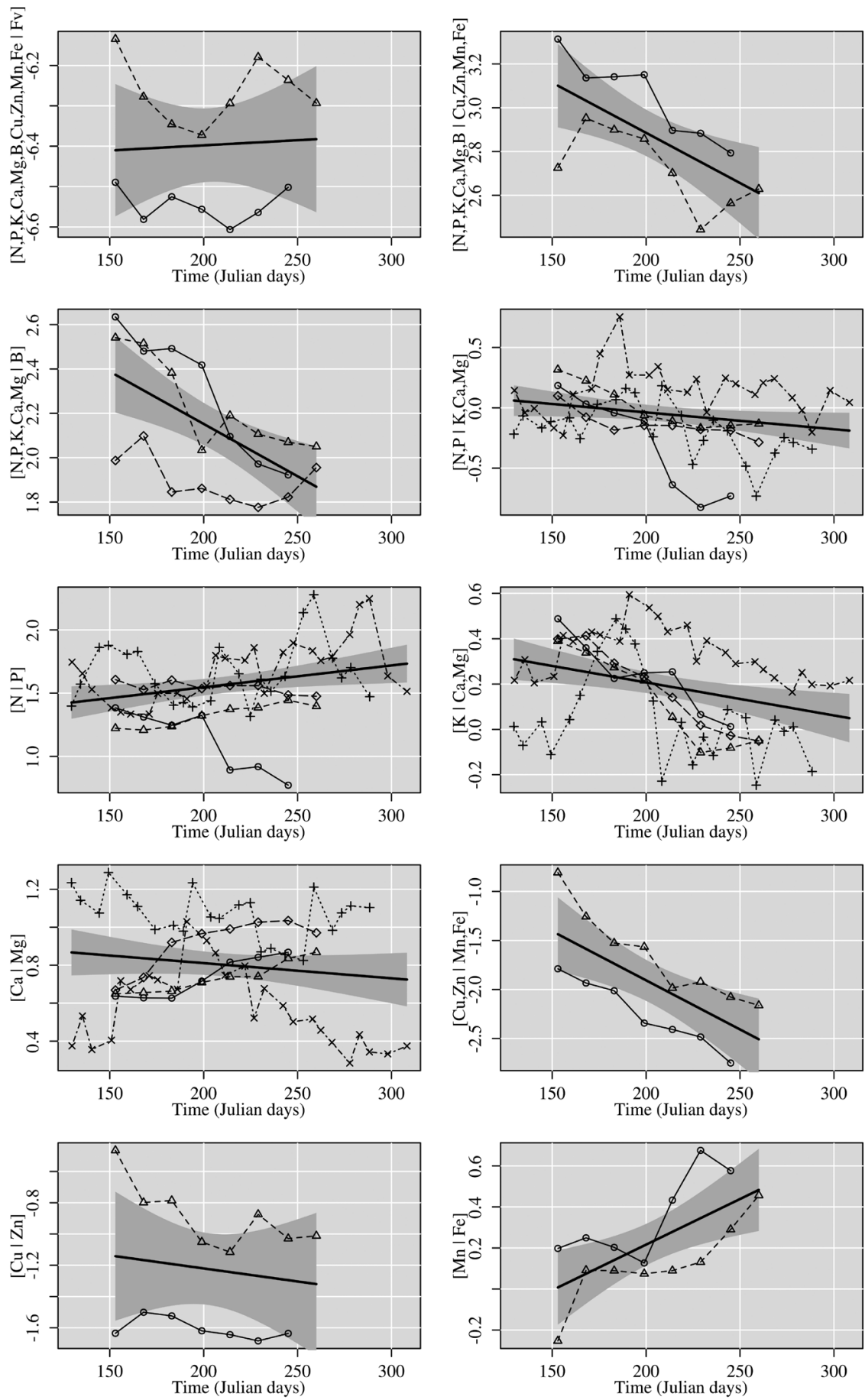

$$
\begin{aligned}
& -\diamond \text { - Year } 1968 \text { (Chaplin \& Martin, 1979) } \\
& \text { —- Year } 1969 \text { (Chaplin \& Martin, 1979) } \\
& \text {--A-Y Year } 1970 \text { (Chaplin \& Martin, 1979) } \\
& \text { … - Year } 1981 \text { (Demoranville \& Deubert, 1986) } \\
& \text {--**-- Year } 1982 \text { (Demoranville \& Deubert, 1986) } \\
& \text { Trend and confidence interval (0.95) }
\end{aligned}
$$

FIGURA 5 - Trend analysis of nutrient balances in cranberry leaves (concentration data retrieved from Chaplin \& Martin, 1979 and DeMoranville \& Deubert, 1986). [N, P, K, Ca, Mg, B, Cu, Zn, $\mathrm{Fe} \mid \mathrm{Fv}],[\mathrm{Ca} \mid \mathrm{Mg}]$ and $[\mathrm{Cu} \mid \mathrm{Zn}]$ are non-significant (i.e. stationary); [N, $\mathrm{P} \mid \mathrm{K}, \mathrm{Ca}, \mathrm{Mg}]$ and $[\mathrm{N} \mid \mathrm{P}]$ are significant at the 0.05 level; others are significant at the 0.01 levels. 


\section{CONCLUSION}

1-The nutrient signature of Quebec cranberry was determined from a 3-yr P fertilizer trial. The leaf analytical data were transformed into ilr coordinates as unbiased indices of nutrient balance. It was derived $i l r$ standards from a subpopulation of cranberry producing $>35 \mathrm{Mg} \mathrm{ha}^{-1}$. The ilr standards were validated against combinations of nutrient concentration ranges used in Maine and Wisconsin, USA.

2-The low-yielding TP specimens in Quebec showed $\mathrm{K}$ and $\mathrm{Fe}$ excess compared to the highyielding TN. The Maine and Wisconsin nutrient ranges converted into balance ranges overlapped several confidence intervals $(\mathrm{P}=0.01)$ of Quebec TN balances. Still, some ranges of nutrient balances in Quebec TN differed significantly from the Wisconsin and Maine computed balance ranges. Differences in nutrient balance ranges may reflect local soil conditions and fertilizer management. Nutrient ranges could be further projected as confidence hyper-ellipses into the Hilbert space in future study using tools of multivariate analysis and geometry. Since trend analysis showed that nutrient balances were generally non stationary, tissue should be sampled at a fixed physiological age or balances should be detrended using empirical equations.

\section{ACKNOWLEDGEMENTS}

This project was funded by the Natural Sciences and Engineering Council of Canada (CG2254; CRDPJ 385199 - 09).

\section{REFERENCES}

AERTS, R.; CHAPIN, F.S. The mineral nutrition of wild plants revisited: a re-evaluation of processes and patterns. Advances in Ecological Research, San Diego, v. 30, p. 1-67, 2000.

AITCHISON J. The Statistical Analysis of Compositional Data. Chapman and Hall, NY, 1986.

BATES, T.E. Factors affecting critical nutrient concentrations in plants and their evaluation: a review. Soil Science, Baltimore, v. 112, p. 116-130, 1971.
CHAPLIN, M.H.; MARTIN, L.W. Seasonal changes in leaf element content of cranberry, Vaccinium macrocarpon Ait. Communications in Soil Science and Plant Analysis, New York, v. 10, p. 895-902, 1979.

CONN, S. J.; GILliHAM, M. Comparative physiology of elemental distributions in plants. Annals of Botany, London, v. 105, p. 1081-1102, 2010.

DAVENPORT, J.; DEMORANVILLE, C.; HART, J.; PATTEN, K.; PETERSON, L.; PLANER, T.; POOLE, A.; ROPER, T.; SMITH, J. Cranberry tissue testing for producing beds in North America. Oregon: Oregon State University, 1995. $4 \mathrm{p}$.

DAVENPORT, J.; PROVOST, J. Cranberry tissue nutrient levels as impacted by three levels of nitrogen fertilizer and their relationship to fruit yield and quality. Communications in Soil Science and Plant Analysis, New York, v. 17, p. 1625-1634, 1994.

DEMORANVILLE, C.; DEUBERT, K. Seasonal patterns of nitrogen, phosphorus, potassium, calcium and magnesium in the leaves of the Massachusetts cranberry. Communications in Soil Science and Plant Analysis, New York, v. 17, p. 869-884, 1986.

EGOZCUE J.J.; PAWLOWSKY-GLAHN, V. Simplicial geometry for compositional data. In: BUCCIANTI A.; MATEU-FIGUERAS, G.; PAWLOWSKY-GLAHN, V. (Ed.). Compositional data analysis in the geosciences: from theory to practice. London: Geological Society, 2006, p. 145159. (Special Publication, 264)

EGOZCUE, J. J.; PAWLOWSKY-GLAHN, V. Groups of parts and their balances in compositional data analysis. Mathematical Geosciences, Heidelberg, v. 37, p. 795-828, 2005.

HAN, W.X.; FANG, J.Y.; REICH, P.B.; WOODWARD, F.I.; WANG, Z.H. Biogeography and variability of eleven mineral elements in plant leaves across gradients of climate, soil and plant functional type in China. Ecology Letters, Davis, v. 14, p.788-796, 2011.

JONES, J. B. JR.; CASE, V.W. Sampling, handling, and analyzing plant tissue samples. In: WESTERMAN, R.L. (Ed.). Soil testing and plant analysis. $3^{\text {rd }}$ ed. Madison: Soil Science Society of America Book, 1990. p. 389-427. 
LAHNER, B.; GONG, J.; MAHMOUDIAN, M.; SMITH, E.L.; ABID, K.B.; ROGERS, E.E.; GUERINOT, M.L.; HARPER, J.F.; WARD, J.M.; MCINTYRE, L. Genomic scale profiling of nutrient and trace elements in Arabidopsis thaliana. Nature Biotechnology, New York, v. 21, p. 1215-1221, 2003.

LOCKHART, C. L. AND LANGILLE, W. M. The mineral content of lowbush blueberry. Canadian Plant Disease Survey, Saskatchewan, v.42, p.124$128,1962$.

MALAVOLTA, E. Manual de nutrição de plantas. Piracicaba: Ceres, 2006.

Marschner, H. Mineral nutrition of higher plants. New York: Academic Press, 1995.

NELSON, L. A.; ANDERSON, R. L. Partitioning of soil test-crop response probability. In: STELLY, M. (Ed.). Soil testing: correlating and interpreting the analytical results. Madison: American Society of Agronomy, 1984. p.19-38. (Special Publication, 29).

PARENT, L.E. Diagnosis of the nutrient compositional space of fruit crops. Revista Brasileira Fruticultura, Jaboticabal, v. 33, p. 321-334, 2011.

PARENT, L.E.; MARCHAND, S. Response to phosphorus of cranberry on high phosphorus testing acid sandy soils. Soil Science Society of America Journal, Madison, v. 70, p. 1914-1921, 2006.
PARENT, L. E.; DAFIR, M. A theoretical concept of compositional nutrient diagnosis. Journal of the American Society for Horticultural Science, Alexandria, v.117, p. 239-242, 1992.

R DEVELOPMENT CORE TEAM. R: a language and environment for statistical computing. Viena: R Foundation for Statistical Computing. Disponível:

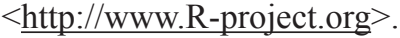

ROPER, T. How much potassium is needed? Wisconsin: Cranberry School Proceedings, 2010. v. 18, p. $23-26$.

ROPER, T. Taking and interpreting soil and tissue samples. Wisconsin: Cranberry School, 2001. v.11, p.16-23.

ROPER, T. The physiology of cranberry yield 2006. Disponível em: $<$ www.hort.wisc.edu/cran $>$.

ROPER, T.R.; VORSA, N. Cranberry: botany and horticulture. Horticultural Review, New York, v. 21, p. 215-249, 1997.

WALWORTH, J. L.; SUMNER, M.E. The Diagnosis and Recommendation Integrated System (DRIS). Advances in Soil Science, New York, v. 6, p. 149$188,1987$.

YARBOROUGH, D.; HEDSTROM, W.; HARKER, J. Cranberry culture. In: LEIBY, J.D. (Ed.). Cranberry agriculture in Maine: a growers guide. Orono: Universtiy Maine, 1993. 